\title{
Negative Features of Female Image in Ossetian Proverbs
}

\author{
Larisa Parsieva ${ }^{1}$, and Larisa Gatsalova ${ }^{2 *}$ \\ ${ }^{1}$ North Ossetian State University, 362025 44-46, Vatutina Street, Vladikavkaz, Republic North Ossetia-Alania, Russia. \\ ${ }^{2}$ North Ossetian Institute for humanitarian _and social research by name VI Abaev, Vladikavkaz scientific center of the RAS \\ Vladikavkaz; 362040 10, Prospect Mira Str., Vladikavkaz, Republic North Ossetia-Alania, Russia.
}

\begin{abstract}
The article deals with the analysis of proverbs and sayings, the semantics of which contributes to the formation of certain ethnic stereotypes of women. Proverbs itemize the image of a woman in her value judgement and explain her behavior based on private and general assessments. By the examples of Ossetian proverbs, the negative features of the concept «woman» are studied according to modes "female gossipiness" and "female intellect". The linguistic and cultural analysis of the paroemias representing the concept "woman" showed that the mentioned concept contains a significant amount of information with a national-cultural character. The authors define the dominant evaluations of a female image, comparing the stereotypes of femininity in the paremias of different languages.
\end{abstract}

\section{Introduction}

The second quarter of the XX - beginning of the XXI centuries were marked in linguistics by rapid development of new research paradigms, based on the principle of anthropocentrism in studies of linguistic phenomena. Great importance in the study of a human in language is being attached to the individual characteristics of the linguistic personality, the most important of which is gender. The gender defines the social, cultural and cognitive position of a human in the world where language plays a major role [1-2].

From the perspective of a gender factor, all aspects of the language can be considered, both at the level of its system and at the level of its functioning, which implies the use of a wide range of methods and techniques that allow studying the reflection of gender in language and speech, as well as involves revealing its cultural specifics [3].

The interest in the manifestation of gender stereotypes in the language and their comparative analysis in different languages and cultures have become the reason why we turned to studying these relations in the paremiological units of the Ossetian language, specifically proverbs and sayings as one of the gender dedicated areas of folklore that carries a certain philosophical and socio-ethical ideal. Of all the aphoristic folklore texts, the focus on the developing the moral feelings of a human and the relationship between people in the family and society is the most inherent to proverbs and sayings. The meaning of proverbs and sayings is formed in a folklore-evaluative environment, so their denotation is the basis for classifying them to a value system of one or another ethnos, but they exist as linguistic units [4].
Despite the fact that paremic expressions give a wide choice for self-identification (and opposite maxims often coexist in the paremiological fund of any language), it is still possible to find in the process of research the dominant evaluations typical for the designated linguocultural community.

\section{Materials and methods}

It is to be noted that when while studying the characterological features of the concept "woman" we faced with the problem of ambiguity, ambivalence, semantic versatility of proverbs and sayings [5], [6]. Let us try to separate from all gender dedicated corpus the proverbs and sayings that characterize a woman from the negative side. Thus, we will get an answer to the question: what kind of woman is considered bad in the Ossetian public consciousness.

Let us mark for ourselves the characteristics by which we will consider paroemies as gender-dedicated, i.e. include them in a common corpus with a "gender" marker. In this particular study, we have one approach: the definition "gender-dedicated" refers to the paremiological units in which we talk about a woman, although gender implies the designation of not only femininity, but also masculinity. The lexical signs of such markedness in this study are the following subconcepts, denoted by the words / word forms of the Ironian and Digor dialects of the Ossetian language (digoric variants are given in parentheses):

сылгоймаг (силгоймаг) - woman,

сыл (силæ) - country woman,

yc (уосæ) - wife,

чызг (кизгæ) - girl.

* Corresponding author: parsieva_larisa@mail.ru 
Paremic units that have an undefined, non-specific, general gender reference, haven't been considered [7], [8]. For example, the following groups of proverbs can be named:

- proverbs, in which the subject is expressed by the word «лаег» not only in the meaning - "man", but also in the meaning - "human". For example:

Лæджы фыд хæрынæн нæ бæззы. - Human flesh isn't good for food.

Къумух лæг æ хуæрзгæнæги дæр нæ зонуй æма æ лæгъузгæнæги дæр. - A stupid man does not know either his friend or the enemy;

- proverbs in which the subject is expressed with word адæймаг "human":

Куыстæй адæймаг нæуæг кæны. - The work praises the man.

Адæймаг дорæй федардæр æй, деденæгæй ба фæлмæндæр. - A man is harder than a stone and softer than a flower;

- $\quad$ proverbs in which the subject is expressed by a noun representing both a man and a woman (so called nouns of common gender). For example:

Евзæр æрвадæй хорз сыхаг хуыздæр. - Better a neighbor nearby than a relative far away.

Иунæг мæгуыр у хъæды дæр æмæ хъæуы дæр. - A lonely person is as poor in the forest as in the village.

Фудгубунæн кувдæй, хистæй уæлдай нæййес - For a glutton feast and funeral feast are the same.

Сæйги æнæнезæй ма фæрсæ. - Don't ask an ill person about his health, etc.

In total, our corpus includes more than 700 proverbs and sayings that are gender dedicated.

What are the negative qualities of a woman being judged in the paremias, i.e. what are the negative qualities being considered unacceptable for an Ossetian woman? Proverbs give the following answer to this question.

\section{Results and discussion}

Traditionally, the universal stereotype is "female chattiness." It is believed that a woman can't be entrusted with a secret: Сылгоймагæн æппæт хабæрттæ дзургæ не сты. - One shouldn't tell a woman everything.

Everyone will know about the secret entrusted to a woman, she can't keep it a priori: Сылгоймаг цы сусæг хъуыддаг зона, уый мауал æмбæхс. - It has no sense to hide a secret known by a woman.

The proverb can teach a woman / wife to talk less, and it can teach a man / husband - to hide the secret from his wife: Уосæн зæрдиуаг зæгъун не 'нгъезуй. - Don't entrust your wife with a secret. Дæ сосæггаг дзубанди дæ уосæн макæд зæгъæ! - Never tell your secrets to the wife! In the paremias of some languages this is a delicate piece of advice, in the paremias of others - a rough comparison. For example, in Ukranian: Silence has never failed a woman. Or a Russian proverb: It is better to sail on a rickety boat in the sea than to entrust a secret to your wife. In the Azerbaijani language, there is a proverb in which the wife is compared to the ox, and this comparison is not in her favor: Tell the ox - no one will know, tell your wife - everyone will know. In the Kurdish language, the analogy is made between a talkative woman and an angry dog: Be afraid of a junkyard dog and a talkative woman. Ossetians believe that the well-being / disadvantage of the family largely depends on the female language: Силæвзаг хæдзари фарнæ нæййес. - There is no happiness if there is a chatty wife in the house. В доме с болтливой женой счастья нет. If a woman has a loose tongue, she can ruin her home, in other words, her family: Усы 'взаг хæдзархалæг. - The tongue of a woman ruins home. In other languages, working capacity or even the life of the man / husband depends on the woman's tongue. So, the Jews say: Men would do more if women spoke less. Or, for example, the Moldavian proverb: If the wife's tongue was shorter, the life of her husband would be longer.

The language of a woman is compared with a cold weapon, for example, in Bulgarian: Female language is sharper than a Turkish sword. It is interesting that in Ossetian the comparison isn't so direct. Here it is the man who is dangerous if he was pitted against someone by his wife: Уосардуд æма хускъинсад кард æнхузон æнцæ. - A husband pitted against someone by his wife is like a knife sharpened without water (ie very sharp). In the Ossetian proverb: Дыууæ æфсымæры кæрæдзийæн амарын кæндзæн "То force brothers kill each other" expresses not only a sign of "loose tongue", but also "cunning".

There is a proverb meaning that to a man's strength a woman can only oppose the tongue: Нæлгоймагæн дыууæ сæры, сылгоймагæн - дыууæ дзыхы. - A man has two heads, while a woman has two mouths (two tongues)

The silence of a woman in the paremias of some nations is jokingly called suspicious, as, for example, in the Jewish proverb: Women lie when they are silent. In fact, the advice that is given to a woman in the Ukrainian proverb The silence has never failed a woman, as well has a certain element of deceit. On the one hand, when she is silent, she does not show her silliness, on the other hand, she also does not say too much about the things that should be kept in secret, no matter how difficult it is.

The idea of women's silliness is also an axiomatic stereotype. It was as well reflected in the proverbial fund.

There are proverbs where a very rough comparison of a woman and a cow is made precisely because of the lack of intelligence: Силгоймаг гъогæй дæр гъæладæр æй. A woman is more stupid than a cow. (Cf. English: When an Ass climbeth a Ladder, you may find Wisdom in Women. Women in state affairs are like monkeys in glass shops).

The female mind is characterized as infantile, not capable of the simplest analytical operations. For example: Иу ус, дам, мæрдджыны хæдзармæ бацыд. Æхсæв-бонмæ фæкуыдта, стæй бафарста: «Чи амарди, чи?» - One woman sat near the house of a deceased all night, crying, and then she asked: "Who died?" This phrase is perceived as a standard of thinking, deprived of any logic, built only on emotions and implied as opposed to rational, objective logic, cold-blooded mind, attributed to masculinity. Or: Сылгоймагæн «Хуыцаумæ цом» зæгъ, æмæ дæ, фæндаг кæуылты у, уымæй нал бафæрсдзæн. - Tell the woman "We are going to God" and she will not even ask you which way; Уосæ раз нæ 
уинуй, фæстæмæ дæр нæ кæсуй; A woman sees nothing in front and does not look back.

As we see, such a figure of speech as an antithesis is used very often, especially to show the extent of female silliness. Traditionally, proverbs oppose long hair to a small intellect, and there are several variations in both Irons and Digor dialects: Сылгоймагæн йæ дзыкку даргъ, йæ. зонд - цыбыр. - Long plait but small intellect; Силæн æ хелæ даргъ æй, æ зунд ба цубур æй æма æнцон сайæн æй. A woman has a long hair, but small intellect, she is easily fooled; Силгоймагæн æ дзиккотæ куд даргъ æнцæ, æ зунд уотæ нæй. The size of woman's intellect isn't as big as the length of her hear.У женщины ум не так долог, как волосы. In Russian there is a similar proverb not only about long hair, but also about a dress: A long dress, but a small intellect.

Female intelligence is perceived as second-rate due to illogicality, irrationality, unpredictability, variability: Усæн къæйæ къæсæрмæ сæдæ фæнды ис. - A woman thinks hundred thoughts while going from the hearth to the threshold. This idea runs through proverbs of other nations, for example, in Russian: The woman has seven Fridays in a week (a woman of many moods); Women's minds are like Tatar bags (fast changing); While the woman is falling from the Russian stove, she has seventyseven thoughts.

Female intelligence also brings griefs: Сылгоймаджы зонд кæдæм фæхæццæ уа, уым фыдбылыз агур. - If a female mind reached somewhere, wait for misfortune there.

A woman is incapable of doing any economic operations, her calculations and actions in this field can cause only devastation, says the Ossetian proverb: Сылгоймаджы зондæй хæдзарыл райсомæй сихормæ хъуг æфты, сихорæй изæрмæ та гал хауы. If you listen to woman's mind, till the breakfast you'll have a cow, till the lunch you'll lose a bull.

There are many proverbs in Ossetian claiming that the main decision-maker in the family should be only a man, for example: Силвæндæ хæдзари бундор не 'вæруй. A house where a woman rules doesn't have basement; Силвæндæ - æвæндæ, а фæстаг ба - гæдибундар. - А house where a woman gives orders stays without advice and is inherited by a cat; Усвæнд хæдзар хæдзар нæу. Уосвæндæ хæдзарæ хæдзарæ нæй. - A house where a woman gives orders isn't home. We haven't met nothing similar in other languages.

A woman, according to proverbs, absolutely can't be an adviser, since she is too silly for this: Силгоймаг (силæ) унаффæгæнæг ку уайдæ, уæд лæгмæ дæр нæ цæуидæ. If a woman was able to decide for herself, she would not be married.

Proverbs are very judgemental of a man who listens to the advice of a woman - he is either considered to be "nicey-nice":Силгоймаги унаффæмæ ци лæг игъоса, йе сили хузæн æй. - A man mentored by a woman is like a woman; Йæ усмæ цы лæг хъусы, уымæн йæ сæрыл сæрбæттæн ис. - A husband who always listens to his wife has a kerchief on his head; or is given the same status as a decedent Уосвæндæ лæг мæрдти нимæдзæй æй. A husband who lives by the advice of his wife is listed among the deceased.
In the paremias there is also a tendency to oppose the male mind to the female: Нæлгоймагæн - дыууæ сæры, сылгоймагæн - дыууæ дзыхы. We can see such an oppositeness in proverbs of other peoples, for example, in Russian: The male mind says: it is necessary, the woman's mind says: I want; Fedora is big, but silly, and Ivan is a little who can go a long way. A man's mind can't understand a woman, since this is basically impossible because of her irrationality. For example, in the Irish: There are only three kinds of men who don't understand women: the young, the old, and the middle-aged. Moreover, odd female logic is a natural phenomenon that can't be understood and explained: There are three things, which are the most difficult to understand: the woman's mind, the work of bees and the breaking wave.

The Russian proverb says that "even if we admit that female mind exists, it is an unusual and, evidently, undesirable phenomenon"[8]: A good woman lives without intellect. This idea is especially apparent in proverbs, which contain advice for men how to choose wives: If you marry an intelligent wife, she'll analyze the holidays. If you marry a clever wife, she won't let you say a word.

However, there is also another mode, in which women's intuition, the only socially approved attribute of a woman in the cognitive sphere, is conceptualized. This quality is contrasted with the male intellect at the level of ordinary consciousness, in some way limited to exceptional rationality and logic [9], [10]. For example, in Russian: A good man talks at large, and a good woman makes a note; The woman's mind is better than any thoughts; Things always look brighter in the morning, wife looks more daring than a husband; In Swedish The female heart sees more than the eyes of ten men. A similar proverb can also be found in the language of the Ganda people: The wife sees more than her husband. In addition, the life experience of a woman and her practical mind, expressed in common sense, are objectified here.

In Ossetian proverbs, this kind of "sight for sore eyes" retrieving the female intellect are proverbs about the Nart saga's heroine Shatana - a wise, cunning and intelligent woman, with whom the best of Nart's husbands descended to ask advice. For example: Сылгоймаг Сатана дæр уыд, фæлæ Нарт йæ зондæй цардысты. - Shatana was also a woman, but the Narts lived following her advice; Хорз æфсин Сатана. Нартæн зонд чи амыдта, йæ дыууадæс къæбицы хæрд æмæ нозтæй дзаг кæмæн уыдысты. - A house-proud woman Shatana taught the Narts and her pantries were always full of food and drinks.

The only paremia of this fragment has a condescending connotation, shown in implicit tolerance to low intellect as stereotyped feminine characteristic: Зунд хестæри кæстæри сæрбæл нæ'й, силгоймаг æма нæлгоймагæй нæй. - Intellect doesn't depend on how old or young you are or on whether you're a man or a woman.

\section{Conclusion}

Thus, in Ossetian, Russian, and other languages, the dominant mode is the one that indicates inability to think deeply, illogicality, irrationality and generally silliness as 
the main characteristics of women [11-12]. Actually in the linguistic consciousness of many people's there were developed stereotyped ideas about a woman as a creature with a single-track mind. The above examples give reason to believe that to the common mind female intellect serves as an example of the backward unformed mind. On this background the cultural-national interpretation of all language expressions is clearly visible: "the female mind is infantile". This is the core of the ordinary mentality, absorbed with the mother's milk along with the language acquisition, and it lives in the self-consciousness of the people, being language and culture beam, the dominant of national self-identification. It should be noted that all of this applies to paremias, which are cultural attitudes to the perception of the female intellect as insufficient and underdeveloped. The stereotyped female mind is opposed to the male and perceived as "subhuman" mind, therefore female activity should be limited exclusively to the "private" sphere.

"Women need a man's mind in order to be guided by it in their behavior. Gender inequality is taken as an axiom and as a fact that men are given the role of legislators for better world order" [13]. As a consequence, in the considered mode the contradictoriness of the concept "woman" is most vividly manifested not only in comparison with the concept of a "man", but also in comparison with the wider concept of a "human".

The reported study was funded by RFBR according to the research project № 18-012-00440 «Active processes in vocabulary of multi-structural languages: internal development and external interaction».

\section{References}

1. A.A. Novozhilova, S.A. Korolkova, A.A. Gureeva, E.A. Shovgenina, V.A. Mityagina, Mediterranean Journal of Social Sciences 6(6), 79-84 (2015)

2. A.A Gureeva, E.Y Novikova, V.A. Mityagina, XLinguae 9(2), 90-102 (2016)

3. Z.V. Kanukova, Sustainable development of mountain areas 3 (21), 121-124 (2014)

4. E. Malushko, O. Maletina, V. Tsybaneva, Training, Advances in Social Science Education and Humanities Research (ASSEHR) 97, 175-180 (2017)

5. E.V. Murugova, Vestnik Volgogradskogo Gosudarstvennogo Universiteta-seriya 2yazykoznanie 16 (2), 197-200 (2017)

6. E.V. Bobyreva, O.A. Dmitrieva, M.R. Zheltukhina, M.V. Busygina, Proceedings of the 7th International Scientific and Practical Conference Current Issues of Linguistics and Didactics: The Interdisciplinary Approach in Humanities (CILDIAH 2017). Advances in Social Science, Education and Humanities Research (ASSEHR) 97, 52-56 (2017)
7. E. Yu. Malushko, International Multidisciplinary Scientific Conferences on Social Sciences and Arts, 1155-1160 (2015)

8. E. Korobova, I. Kardovich, D. Mironova, M. Konysheva, Advances in Social Science Education and Humanities Research (ASSEHR) 97, 119-124 (2017)

9. L.N. Rebrina, E.Yu. Malushko, Advances in Social Science Education and Humanities Research (ASSEHR) 97, 233-238 (2017)

10. V.N. Teliya, Russian phraseology. Semantic, pragmatic and linguocultural aspects, (M.: school "Languages of Russian culture", 1996)

11. L.K. Parsieva, L.B Gatsalova, Journal of Language and Literature 5(4), 217-219 (2014)

12. L.B Gatsalova, L.K. Parsieva, Science Journal of Volgograd State University. Linguistics 4 (28), 138143. (2015).

13. G. Halifax, The Lady's New Year's Gift: or Advice to a Daughter (SPb: Aletheia, 2001) 